\title{
An Archaeological Survey of a Proposed Well Pad in the Vicinity of Lake Corpus Christi, San Particio County, Texas
}

Paul D. Lukowski

Follow this and additional works at: https://scholarworks.sfasu.edu/ita

Part of the American Material Culture Commons, Archaeological Anthropology Commons, Environmental Studies Commons, Other American Studies Commons, Other Arts and Humanities Commons, Other History of Art, Architecture, and Archaeology Commons, and the United States History Commons

Tell us how this article helped you.

This Article is brought to you for free and open access by the Center for Regional Heritage Research at SFA ScholarWorks. It has been accepted for inclusion in Index of Texas Archaeology: Open Access Gray Literature from the Lone Star State by an authorized editor of SFA ScholarWorks. For more information, please contact cdsscholarworks@sfasu.edu. 


\section{An Archaeological Survey of a Proposed Well Pad in the Vicinity of Lake Corpus Christi, San Particio County, Texas}

\section{Creative Commons License}

\section{(c) (1) \&}

This work is licensed under a Creative Commons Attribution-NonCommercial 4.0 International License 
AN ARCHAEOLOGICAL SURVEY OF A PROPOSED WELL PAD

IN THE VICINITY OF LAKE CORPUS CHRISTI,

SAN PATRICIO COUNTY, TEXAS

Paul D. Lukowski

Center for Archaeological Research

The University of Texas at San Antonio

Archaeological Survey Report, No. 134 

AN ARCHAEOLOGICAL SURVEY OF A PROPOSED WELL PAD

IN THE VICINITY OF LAKE CORPUS CHRISTI,

SAN PATRICIO COUNTY, TEXAS

Pau1 D. Lukowski

Investigations conducted under

Texas Antiquities Committee Permit No. 330

Center for Archaeological Research

The University of Texas at San Antonio ${ }^{\circledR}$

Archaeological Survey Report, No. 134 
The following information is provided in accordance with General Rules of Practice and Procedure, Chapter 41.11 (Investigation Reports), Texas Antiquities Committee:

1. Type of investigation: Pedestrian survey of a well pad site in the vicinity of Lake Corpus Christi, San Patricio County, Texas;

2. Project name: Lake Corpus Christi Well Pad;

3. County: San Patricio County, Texas;

4. Principal Investigator: Thomas R. Hester; Co-Principal Investigator: Jack D. Eaton; Field Director: Paul D. Lukowski;

5. Name and location of sponsoring agency: John R. Thompson Operating, Inc., Abilene, Texas;

6. Texas Antiquities Committee Permit No. 330.

A list of publications offered by the Center for Archaeological Research can be obtained by sending $\$ 1.00$ to the Center for Archaeological Research, The University of Texas at San Antonio, San Antonio, Texas 78285. 


\begin{abstract}
On October 13, 1982, the Center for Archaeological Research, The University of Texas at San Antonio, carried out a pedestrian survey of a well pad site at Lake Corpus Christi State Park in San Patricio County. The survey located a prehistoric site (41 SP 116). However, surface examination and shovel testing determined that the site was not a significant cultural resource. Therefore, no further work is recommended.
\end{abstract}




\section{TABLE OF CONTENTS}

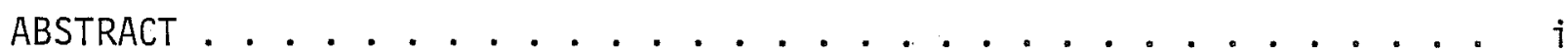

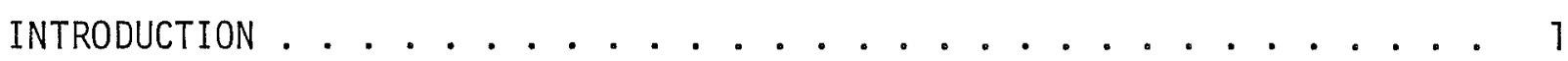

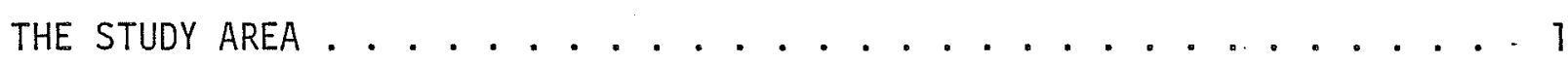
ARCHAEOLOGICAL AND HISTORICAL BACKGROUND ............... 1

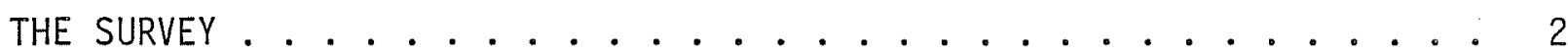

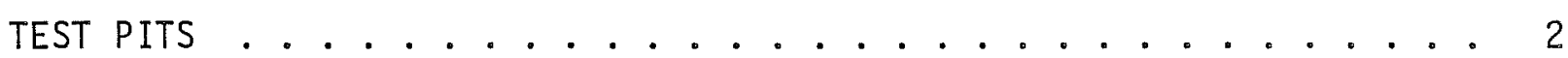

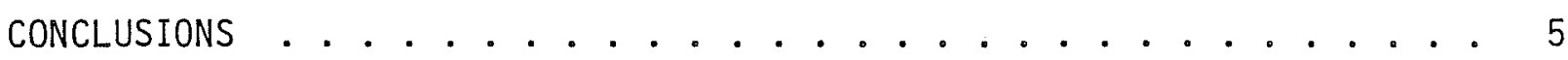
SUMMARY AND RECOMMENDATIONS ................ 5

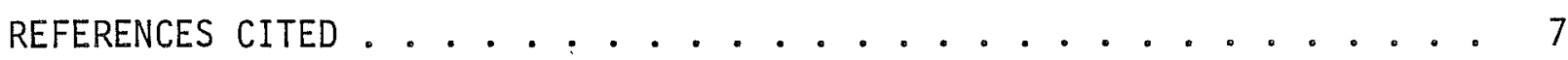

\section{LIST OF FIGURES}

Figure 1. Location of Survey Study Area and 41 SP $116 \ldots 3$ Figure 2. Field Sketch Map of 41 SP 116 and Location of Test Units. . 4

$$
\text { LIST OF TABLES }
$$

Table 1. Provenience Table of Collected Artifacts at 41 SP $116 \ldots 6$ 


\section{INTRODUCTION}

On October 13, 1982, the Center for Archaeological Research (CAR), The University of Texas at San Antonio (UTSA), carried out an archaeological survey of a proposed well pad site on land currently leased by the Texas Parks and Wild1ife Department. The well pad site lies adjacent to Lake Corpus Christi State Recreational Area near the town of Mathis, Texas. The project was carried out under contract between the John R. Thompson Operating, Inc., and the CAR-UTSA (letter dated October 7, 1982). The survey was done under Texas Antiquities Committee Permit No. 330. The field work was conducted by PauT D. Lukowski, Center staff archaeologist, under the general supervision of $\mathrm{Dr}$. Thomas R. Hester, Director, and Mr. Jack D. Eaton, Associate Director. As a result of the survey, a prehistoric site (41 SP 116) was recorded. Al1 field notes and cultural materials recovered from the site are stored at the Center for Archaeological Research.

\section{THE STUDY AREA}

The proposed well pad is located at approximately 610,420E 3,103,600N (Universal Transmetric Grid) and can be located on the USGS Sandia quadrangle, 7.5 minute series. The pad site sits on a ridge that extends out into Lake Corpus Christi, slightly northwest of the lake dam. The survey area 7 ies within the South Texas Plains vegetational area; however, most of San Patricio County lies within the Gulf Prairies and Marshes region (Gould 1972).

Mesquite and prickly pear dominate the brushy area of the ridge, but the proposed pad area has been cleared and extensively modified to serve as a fishing resort camp. In the immediate camp area, there are three standing structures (cabins), and also concrete foundations marking the location of other recent structures. Mulberries, palms, and grasses have been planted in the fishing camp.

\section{ARCHAEOLOGICAL AND HISTORICAL BACKGROUND}

Archaeological research in the Lake Corpus Christi area, where the three counties of San Patricio, Jim Wells, and Live Oak meet, has been very 1 imited. The lake was constructed prior to state or federal regulations that required archaeological studies. Most areas that would have been predictable locales for prehistoric occupation sites are now inundated by the lake. Periodically, as lake levels are lowered by drought, sites are re-exposed and are subjected to extensive relic collecting. State agencies responsible for the protection of cultural resources within the lake area should take steps to inventory these sites at times of low lake levels and to protect them from indiscriminate collecting. Similarly, some areas around the lake are owned or controlled by public agencies and are known to contain archaeological sites. For example, T. R. Hester reported in 1983, to the Texas Historical Commission and the Texas Antiquities Committee, the presence of a site on property owned by the City of Corpus Christi on the edge of the lake. The property is leased to a private concern for a public campground. A site on the property has been subjected to damage in the past and is 
currently being collected with no apparent interdiction from the State. Within the past few months, K. L. Brown of the University of Houston has conducted a we1l-pad survey in the vicinity of the survey area described in this report. No cultural resources were found (K. L. Brown, personal communication).

Upstream on the Nueces and Frio River drainages, archaeological work has been conducted at the Choke Canyon Reservoir and at site 41 LK 28, a Middle to Late Archaic cemetery (see Hester 1980 for summaries). Downstream from Mathis, along the Nueces River, Chandler, Knolle, and Knolle (1983) has reported Paleo-Indian artifacts from the knolle farms. Also in the region, field work has been conducted at site $41 \mathrm{JW} 8$ in Jim Wells County (see Hester 1980), at site 41 NU 63 near Banquete (Black 1978), and at several surface-exposed sites to the east, along Chiltipin Creek, in San Patricio County (e.g., Chandler 1983).

For historical background on towns, place names, and other local features in the area, see Webb (1952) and Branda (1976). Other historical summaries and bibliographies have been published by Frkuska (1979) and by Mokry (in B1ack 1978).

\section{THE SURVEY}

The survey area was delimited by the size of the proposed well pad, an area 200 feet by 200 feet, and centered around a staked dri11 point. This area, less than an acre in size, was completely covered by a careful surface inspection. The ground visibility was very good in this area, and two chert flakes were noted. A larger area surrounding the proposed well pad was also surface inspected, including nearly all of the ridge shown in Figure 1. Cultural material in the area surrounding the proposed well pad was slight, consisting of a few widely scattered flakes and a single tool (a graver made on a flake). None of the lithics on the site's surface were collected. However, on the shores of the lake, a small beach area (about three meters in width and surrounding the point of the ridge) contained a relatively high amount of lithics. Several items, which included a small, thick, gougelike tool of petrified wood, a vaguely Guadalupe-like form, a split-cobble core, and a bifacially flaked core, were noted and collected as part of a grab sampling from the beach area. As there was little evidence that the lithics on the beach had washed down the slope from higher elevations, it seems likely that the materials were accumulated through deflation of the sandy loams, which can be seen in profile along the shores of the ridge. The profiles would indicate approximately a meter or less of sandy loam overlying a more clayey stratum.

\section{TEST PITS}

Two shovel tests, both measuring 50 by $50 \mathrm{~cm}$ in size, were excavated within the defined boundaries of the proposed well pad to determine if subsurface deposits were present (Fig. 2).

Test Pit 1 was located nine meters from the staked drill point and at a bearing of $265^{\circ}$ (magnetic north). The test pit was excavated to a total depth of $65 \mathrm{~cm}$ below the ground surface. From 0 to $55 \mathrm{~cm}$ the soil consisted of a wet, undifferentiated, loose brown sandy loam; below $55 \mathrm{~cm}$ a distinct soil change to a 
This page has been

redacted because it

contains restricted

information. 
This page has been

redacted because it

contains restricted

information. 
dry and compacted brown sandy loam was noted. By far, most of the screened recovery from Test Pit 1 was of recent origin. Wire nails, small slivers of earthenware, clear glass (some partly melted), and concrete rubble were common to a depth of $40 \mathrm{~cm}$. The prehistoric remains consisted of a few flakes and chips, with the highest frequency noted in level $2(20-40 \mathrm{~cm})$. The materials recovered from both test pits are 7 isted in Table 1 .

Test Pit 2 was located $29 \mathrm{~m}$ from the staked drill point and at a bearing of $127^{\circ}$ (magnetic north). The test was excavated to a total depth of $95 \mathrm{~cm}$ below the ground surface. The upper $10 \mathrm{~cm}$ consisted of a loose brown sandy loam similar to that described for Test Pit 1. At approximately $10 \mathrm{~cm}$ to $52 \mathrm{~cm}$, the soil was a wet, tan silty sandy loam mottled with decomposed white calcium carbonate inclusions. At $52 \mathrm{~cm}$ a third distinct soil change was noted. The soil was lighter tan, more silty, and dry from 52 to $95 \mathrm{~cm}$. Cultural material was confined to the first soil zone, and included a single chert specimen, a fragment of mussel shel1, and recent refuse (plastic, a pop-top, wire nails, and glass).

\section{CONCLUSIONS}

A check with the Texas Archeological Research Laboratory (TARL) revealed that no sites had been previously recorded in the immediate vicinity of the study area. The presence of a light lithic scatter across the ridge in the vicinity of the proposed well pad suggests that a prehistoric activity locus was situated here, and at one time it was less than $250 \mathrm{~m}$ from the Nueces River channel. This should be considered in any future archaeological surveys of the area. The presence of cores and a variety of tool forms further suggest that specific tasks were performed nearby. However, due to extensive land modifications in the past, the mixing with modern refuse, and the overall low 1ithic density as indicated by both surface survey and test pits, site 41 SP 116 does not seem to represent a significant enough resource to warrant mitigation measures.

\section{SUMMARY AND RECOMMENDATIONS}

The surface survey of the proposed well pad site resulted in the identification and recording of a previously unknown prehistoric resource. Site 41 SP 116 was defined as a light lithic scatter occurring over the ridge containing the proposed well pad location. The scatter covers an area estimated to be 250 by $100 \mathrm{~m}$ in size and oriented along the axis of the ridge. The cultural remains in the pad area suggest the site was an infrequently used open campsite of an undetermined chronological age. Recent land modifications and introduction of modern cultural debris has seriously impacted the surface and subsurface contexts of the site. In our opinion, the site is not eligible for state Archeological Landmark status or nomination to the National Register of Historic Places. Therefore, no further work is recommended. However, should extensive cultural remains be unearthed during the well pad construction, an archaeologist should be consulted. 
TABLE 1. PROVENIENCE TABLE OF COLLECTED ARTIFACTS AT 41 SP 116

\begin{tabular}{|c|c|c|c|c|c|c|c|}
\hline & & & $\mathrm{P}-1 \quad(\mathrm{~cm}$ & & & $\mathrm{p}-2(\mathrm{~cm}$ & \\
\hline ITEM & Surface & $0-20$ & $20-40$ & $40-65$ & $0-20$ & $20-52$ & $52-95$ \\
\hline Earthenware & & 4 & 2 & & & & \\
\hline Nails & & 6 & 5 & & & & \\
\hline Glass & & 9 & 6 & & 1 & & \\
\hline Plastic & & 1 & & & 1 & & \\
\hline Other Metal & & & & & 2 & & \\
\hline $\begin{array}{l}\text { Concrete } \\
\text { Fragments }\end{array}$ & & 15 & 8 & & & & \\
\hline $\begin{array}{l}\text { Secondary } \\
\text { Flake/Chip }\end{array}$ & 5 & 1 & 5 & & 1 & & \\
\hline $\begin{array}{l}\text { Interior } \\
\text { Flake/Chip }\end{array}$ & 3 & 2 & 3 & & & & \\
\hline Gouge & 2 & & & & & & \\
\hline Core & 4 & & & & & & \\
\hline
\end{tabular}




\section{REFERENCES CITED}

Black, S. L.

1978 Archaeological Investigations at the Banquete Bend Site

(41 NU 63), Nueces County, Texas. Center for Archaeological

Research, The University of Texas at San Antonio, Archaeological

Survey Report 63.

Branda, E. C., ed.

1976 The Handbook of Texas. Vo1. 3. Texas State Historical

Association, Austin.

Chandler, C. K.

1983 Notes on Some Bell Points from San Patricio County, Texas. La Tierra 10(3):7-10.

Chandler, C. K., F. Knolle, and M. M. Knolle

1983 Paleo-Indian Projectile Points from Jim We17s and Nueces

Counties, Texas. La Tierra 10(2):23-27.

Frkuska, E.

1979 Historical Assessment of the Proposed Pipeline Route. In A Preliminary Archaeological and Historical Assessment of the Proposed Tenneco Pipeline, Hidalgo to Victoria Counties, Texas, edited by T. R. Hester:37-41. Center for Archaeological Research, The University of Texas at San Antonio, Archaeological Survey Report 51.

Gould, F. W.

1972 Texas Plants. A Checklist and Ecological Summary. Texas A\&M Experiment Station-Extension Service, Leaflet 492.

Hester, T. R.

1980 Digging Into South Texas Prehistory. Corona Publishing Company, San Antonio, Texas.

Webb, W. P., ed.

1952 The Handbook of Texas. Vols. 1 and 2. Texas State Historical Association, Austin. 
